\title{
Isolation and Characterization of Indole Acetic Acid Producing Halophilic Bacteria from Salt Affected Soil of Rice-Shrimp Farming System in the Mekong Delta, Vietnam
}

\author{
Nguyen Khoi Nghia*, Tran Thi My Tien, Nguyen Thi Kieu Oanh, Nguyen Hoang Kim Nuong \\ Department of Soil Science, College of Agriculture and Applied Biology, Cantho University, Cantho City, Vietnam
}

Email address:

nknghia@ctu.edu.vn (N. K. Nghia)

${ }^{*}$ Corresponding author

To cite this article:

Nguyen Khoi Nghia, Tran Thi My Tien, Nguyen Thi Kieu Oanh, Nguyen Hoang Kim Nuong. Isolation and Characterization of Indole Acetic Acid Producing Halophilic Bacteria from Salt Affected Soil of Rice-Shrimp Farming System in the Mekong Delta, Vietnam. Agriculture, Forestry and Fisheries. Vol. 6, No. 3, 2017, pp. 69-77. doi: 10.11648/j.aff.20170603.11

Received: April 4, 2017; Accepted: April 13, 2017; Published: May 17, 2017

\begin{abstract}
The main aim of this study was to deal with isolation, characterization and identification IAA producing bacteria from paddy rice cultivated soil samples collected in rice-shrimp farming system in salt affected areas of the Mekong Delta of Vietnam. Fifteen soil samples collected from the rice crop in the rice-shrimp farming system of 5 different provinces within the Mekong Delta, Vietnam were used to isolate the IAA producing bacteria. NBRIP media was used to isolate the potentially IAA producing bacteria. Result showed that 213 isolates were obtained from the fifteen different soil samples. Out of 45 indole acetic acid producing isolates, ten were selected as efficient producers. One out of ten, the isolate ST2-1 was identified as the most promising strain as efficient biofertilizer inoculants to promote plant growth. This strain produced $33.13 \mathrm{mg} . \mathrm{L}^{-1}$ as the highest concentration of IAA after 8 days of incubation. As well, this strain stimulated the growth of rice's roots and dry biomass after 7 days of experiment with Hoagland medium containing $0.3 \% \mathrm{NaCl}$ in $100 \mathrm{~mL}$ glass tube. This strain produced well IAA production in $\mathrm{pH}$ variation range of medium between 5 and 9 and this bacterial strain can resist to salinity of environment up to $3 \% \mathrm{NaCl}$. However, this bacterial was highly inhibited by not only 3 commonly used antibiotics: Ampicillin, Chloramphenicol and Steptomycin at recommended rates but also 3 plant pathology fungicides: Thiophanate Methyl, Propineb and Mancozed regarding to IAA production ability. The results of the 16S rRNA gene sequence analysis showed that this IAA producer coded as ST2-1 was genetically identified as species of Bacillus megaterium ST2-9 since $99 \%$ of its sequence affiliated with Bacillus megaterium. In conclusion, the study suggests the IAA producing bacteria as efficient biofertilizer inoculants to promote plant growth.
\end{abstract}

Keywords: Bacillus Megaterium, Bacteria, Indole-3-Acetic Acid (IAA), Rice-Shrimp Farming System, Salt Affected Soil and 16S rRNA

\section{Introduction}

Indole-3-acetic acid (IAA), a plant hormone compound, is a natural auxin produced by plants, algae, mosses, lichens and a diverse group of organisms. It is a metabolite derived from tryptophan (Trp) by many Trp-dependant and Trpindependent pathways in plants and bacteria. There is more than one pathway could be present in a bacterium [1]. Azospirillum brasilense has been reported as physiological evidence for different Trp-dependent pathways for synthesis [2]. In Trp dependant pathway, tryptophan is converted to indole-3-acetamide (IAM) by tryptophan-2-monooxigenase and IAM is metabolized to IAA by IAM-hydrolase [3]. A study of Horemans and Vlassak (1985) [4] revealed that Azosporillum brasilense could produce IAA in the absence of tryptophan when grown aerobically and the highest levels of auxin were produced in the presence of $\mathrm{NH}_{4}^{+}$. Among IAA producing organisms, soil microorganisms, especially bacteria which reside in soil rhizosphere or as free living bacteria in soil can also produce IAA [5, 1] as well as bacteria associated with plants [6]. Many studies have focused in regarding the physiological effects of bacterial 
production of IAA on plants and its possible role as a phytohormone in plant-microbe interaction. Tryptophan has been identified as a main precursor for IAA biosynthesis pathways in bacteria [1].

IAA has since been implicated in virtually all aspects of plant growth and development [7]. It is produced by free bacteria. They reside in various habitats ranging from hot springs to brackish and hypersaline coastal environments [8]. These habitats are extreme environments because high salt concentrations are hostile to most organisms. However, many organisms, particularly prokaryotic and eukaryotic microorganisms can inhabit and survive in these environments due to their ability to cope with osmotic stress. These microorganisms have many mechanisms to protect their cells from high osmotic pressure and against the denaturing effect of salts. They play an important role as primary producers in these ecosystems [9]. IAA is a common product of L- tryptophan metabolism produced by several microorganisms including Plant Growth-Promoting Rhizobacteria (PGPR) [10]. Bacteria that colonize the rhizosphere and plant roots and as well as the one which reside freely in soil can enhance plant growth by many mechanisms referred to as PGPR. PGPR can exhibit a variety of characteristics responsible for influencing plant growth. The common representatives are auxin, gibberellin, ethylene, siderophores, HCN and antibiotics [11]. Microorganisms synthesize IAA for their own benefit [12]. Many microorganisms from rhizosphere region of various crops have an ability to produce IAA as secondary metabolites due to rich supply of substrates. IAA helps in the production of longer roots with increased number of root hairs and root laterals which are involved in nutrient uptake [13]. IAA stimulates cell elongation by modifying certain conditions like, increase in osmotic contents of the cell, increase in permeability of water into cell, decrease in wall pressure, an increase in cell wall synthesis and inducing specific RXA and protein synthesis. It enhances embial activity, inhibit or delay abscission of leaves, induce flowering and fruiting [14].

Many species and specific strains of bacteria residing in rhizosphere and in soil can possess plant growth promoting traits and hence they are collectively designated as plant growth promoting rhizobacteria (PGPR) [15]. There are many mechanisms of PGPR to enhance plant productivity. Direct promotion of growth by PGPR occurs when plant growth hormones such as auxins [16], cytokinins [17] and gibberellins [18] as well as through the solubilization of phosphate minerals [19] are produced by the rhizobacteria whilst indirect growth promotion presents through the elimination of pathogens by the production of cyanide [20] and siderophores [21]. Their plant growth promoting activities include production of $\mathrm{HCN}$, siderophores, protease, antimicrobials, phosphate solubilizing enzymes [22]. Since the beginning of last century, many IAA producing microorganisms have been isolated including, for example, those in Stryptomyces sp. [23], Bacillus subtilis spp [1], Enterobacter cloacae [24], Pseudomonas syringae [25],
Pseudomonas fluorescens [26], Agrobacterium tumefaciens, Alcaligenes faecalis and Azotobacter tumefaciens [27]. The microorganisms functioning similarly also include some fungi, for example, Pisolithus tinctorius, Suillus variegatus, Suillus granulatu, Aspergillus niger strain BHUAS01, Penicillium citrinum strain BHUPC01 and Trichoderma harzianum [28]. Unfortunately, most IAA producing bacteria isolated previously performed relatively low salinity tolerance, being less appropriate for saline-alkali soil-based agriculture. It is urgently needed to isolate highly halophilic IAA producing bacteria for the development of saline-alkali soil-based agriculture. In this study, a moderately halophilic, IAA producing bacterium ST2-1 was isolated and characterized. The first objective of this study was to isolate and screen indigenous Indole acetic acid producing bacteria from different soil in rice-shrimp rotational farming system in salt affected soil. The second was to purify the IAA and screen their abilities of plant growth promoting bacteria attributes. Besides, optimization study intended for high IAA production was carried out with physicochemical parameters such as $\mathrm{pH}, \mathrm{NaCl}$, antibiotics and fungicides without supplement of tryptophan. An attempt was made to isolate and screen the IAA producing bacteria with an objective to develop them as bio-inoculants, for selected crop plants.

\section{Materials and Methods}

\subsection{Isolation of IAA Producing Bacteria in Soils}

Topsoil $(0-20 \mathrm{~cm})$ was sampled from fifteen rice-shrimp fields in coastal provinces of Mekong Delta including Bac Lieu, Ben Tre, Ca Mau, Kien Giang and Soc Trang with the three samples at each sampling place and properties of the chemical and biological soil samples were presented in Table 1. $\mathrm{pH}$ in soil samples are from 7.9 to 8.9 that are moderately and strongly alkaline except BL4, BT1, BT5, ST5 and ST6 that are neutral ( $\mathrm{pH}$ from 6.9 to 7.2$)$ and strongly acidic $(\mathrm{pH}$ from 3.7 to 5.0), and all soil samples are evaluated high EC value (4.08 and $\left.42.20 \mathrm{mS} . \mathrm{cm}^{-1}\right)$ and they are saline soil and salt affected soil or saline acid sulphate soil [29].

After collecting samples from the fields, $10 \mathrm{~g}$ of soil was taken and put in $250 \mathrm{~mL}$ bottle and added $90 \mathrm{~mL}$ sterile phosphate buffer solution. Phosphate buffer solution contains $23.99 \mathrm{~g} \mathrm{NaH}_{2} \mathrm{PO}_{4}$ and $15.59 \mathrm{~g} \mathrm{Na}_{2} \mathrm{HPO}_{4}$ in $1 \mathrm{~L}$ distilled water and then this solution was autoclaved in autoclave machine at $121{ }^{\circ} \mathrm{C}$ in 20 minutes. The sample bottles were shaken vigorously at $150 \mathrm{rpm}$ for 1 hour (Bio-shaker BR-300LF, Taitec, Nagoya, Japan) and the soil suspensions were serially diluted to $10^{-5}$ (dilution factor $=10$ ). An aliquot of $50 \mu \mathrm{L}$ diluted samples were spread on NBRIP agar plates [30] which contained the following ingredients $\left(\mathrm{g} . \mathrm{L}^{-1}\right)$ : glucose, 10.0; tricalcium phosphate (TCP), $10.0 ; \mathrm{MgCl}_{2} \cdot 6 \mathrm{H}_{2} \mathrm{O}, 5.0$; $\mathrm{MgSO}_{4} .7 \mathrm{H}_{2} \mathrm{O}, 0.25 ; \mathrm{KCl}, 0.2 ;\left(\mathrm{NH}_{4}\right)_{2} \mathrm{SO}_{4}, 0.1$. This NBRIP medium was supplied with $1 \%$ sodium chloride. The sample agar plates were incubated in incubator for 3 days at $30^{\circ} \mathrm{C}$. Single colony was picked up and streaked consecutively on fresh NBRIP agar plates in 5 times to get pure cultures and 
isolated colonies were observed for colony and cell morphology characterization.

Total 213 strains were obtained and considered potentially as IAA producing bacteria from 15 soil samples and among which 45 isolates were qualitatively identified as IAA producing bacteria via the qualitative assay of IAA produced by isolated strains was conducted on the basis of Brick et al. (1991) [31] proposed method and they were further checked for quantitative IAA assay.

Table 1. Chemical and biological soil properties of the studied soils.

\begin{tabular}{|c|c|c|c|c|c|c|}
\hline Soil & Code & $\begin{array}{l}\mathrm{pH} \\
(1: 2.5)\end{array}$ & $\begin{array}{l}\text { EC } \\
(1: 2.5){\left.\mathrm{mS} . \mathrm{cm}^{-1}\right)}^{-1}\end{array}$ & $\begin{array}{l}\text { Available P } \\
\left(\mathrm{mgP.kg}^{-1}\right)\end{array}$ & $\begin{array}{l}\mathrm{NH}_{4}^{+} \\
\left(\mathrm{mgN}^{+} \mathrm{kg}^{-1}\right)\end{array}$ & $\begin{array}{l}\text { Bacteria density } \\
\left(\log \text { CFU.g- }{ }^{1} \text { soil }^{-1}\right)\end{array}$ \\
\hline \multirow{3}{*}{ Bac Lieu } & BL1 & 8.2 & 9.41 & 0.0071 & 0.544 & 5.52 \\
\hline & BL4 & 7.2 & 12.20 & 0.0153 & 1.083 & 5.93 \\
\hline & BL6 & 8.0 & 11.71 & 0.0059 & 0.872 & 5.74 \\
\hline \multirow{3}{*}{ Ben Tre } & BT1 & 3.7 & 12.77 & 0.0030 & 1.217 & 5.21 \\
\hline & BT2 & 8.6 & 9.12 & 0.0036 & 0.593 & 5.59 \\
\hline & BT5 & 3.8 & 10.65 & 0.0089 & 0.196 & 4.97 \\
\hline \multirow[t]{2}{*}{$\mathrm{Ca} \mathrm{Mau}$} & CM4 & 8.5 & 33.60 & 0.0107 & 1.364 & 6.34 \\
\hline & CM6 & 8.5 & 31.90 & 0.0065 & 1.500 & 6.05 \\
\hline \multirow{3}{*}{ Kien Giang } & KG2 & 8.7 & 21.00 & 0.0012 & 1.663 & 5.24 \\
\hline & KG3 & 8.9 & 15.14 & 0.0125 & 1.082 & 5.18 \\
\hline & KG4 & 8.8 & 17.06 & 0.0024 & 1.452 & 5.69 \\
\hline \multirow[b]{2}{*}{ Soc Trang } & ST2 & 8.3 & 4.08 & 0.0048 & 0.765 & 6.04 \\
\hline & ST5 & 6.9 & 6.69 & 0.0101 & 0.432 & 5.74 \\
\hline
\end{tabular}

\subsection{Characterization of IAA Production Potential}

Forty five out of 213 bacterial isolates were identified qualitatively as IAA producing bacteria from a qualitative assay. These isolates were tested to determine the amount of IAA produced by each bacterial strain. Each bacterial strain was grown in $150 \mathrm{~mL}$ Erlenmeyer flask containing $50 \mathrm{~mL}$ Tryptose Soybean Broth (TSB) medium supplied 1\% sodium chloride. The composition of TSB contains (g.L $\mathrm{L}^{-1}$ ) Tryptose Soybean Broth, 30.0 and agar, 15.0 in $1 \mathrm{~L}$ distilled water and then it was sterilized at $121^{\circ} \mathrm{C}$ for 20 minutes. All sample flasks were incubated on the shaker at room temperature $\left(30^{\circ} \mathrm{C}\right), 100 \mathrm{rpm}$ for 3 days in the dark (Bio-shaker BR300LF, Taitec, Nagoya, Japan). Then microbial biomass was harvested by centrifugation at $2500 \times \mathrm{g}$ for 10 minutes. In order to remove completely nutrient from TSB medium, sterilized deionized water was used to wash the microbial biomass by means of centrifugation and this process was repeated consecutively for 4 times. Microbial suspension with sterilized deionized water was calibrated to optical density $\left(\mathrm{OD}_{660 \mathrm{~nm}}=0.7\right)$. Initial bacterial numbers of each isolate were determined after achieving optical density of 0.7 at $660 \mathrm{~nm}$ by spreading $100 \mu \mathrm{L}$ of each diluted concentration of each bacterial suspension on TSB agar medium. Each isolate was incubated in NBRIP liquid media for 12 days in the dark on the orbital shaker at $100 \mathrm{rpm}$ (Bio-shaker BR300LF, Taitec, Nagoya, Japan) and concentration of IAA production was determined by Salkowski reagent at a $530 \mathrm{~nm}$ wavelength [31].

\subsection{Effect of IAA Producing Bacterial Isolates on Plant Growth by Glass Tube Assay}

To study the effect of IAA producing bacteria on plant growth, an experiment was conducted in glass tube. The best
10 bacterial isolates showed their ability in producing IAA compound in NBRIP liquid medium among 45 selected strains were chosen for this assay. These isolate names were as follows: BT1-1; CM6-1; CM6-2; CM6-4; KG3-1; KG4-1; KG4-2; ST2-1 and ST6-1. Rice seed variety so called "Mot Bui Do" was chosen as cultivar for this assay due to it can tolerate with the water salinity up to $0.3 \%$ and is the most common used rice variety in the coastal area of Vietnamese Mekong Delta. Hoagland's nutrient solution [32] containing $0.3 \%$ sodium chloride was used as nutrient solution for rice and bacterial isolates to develop. This solution was sterilized at $121^{\circ} \mathrm{C}$ for 20 minutes. Rice seeds were removed peels, then sterilized with $1 \%$ sodium hypochlorite solution for 10 minutes and $70^{\circ}$ alcohol for 1 minute following washed consecutively with sterilized deionized water for four times. Then peeled rice seeds were incubated on $1 \%$ agar plates in the dark and at room temperature for 3 days. After germinating, a rice seedling was placed on a sterilized cotton ball placed on surface of Hoagland's nutrient solution to keep the rice seedling not submerged in a sterilized $100 \mathrm{~mL}$ glass tube including $10 \mathrm{~mL}$ Hoagland's nutrient solution. The bacterial suspension of each isolate was prepared the same way as the "Characterization of IAA production" part. The initial bacterial number of each isolate was determined after achieving optical density of 0.7 at $660 \mathrm{~nm}$. The experiment was carried out in 11 treatments including 10 bacterial strains and a control (without bacteria) with four replications for each treatment at room temperature under a static condition. At the $7^{\text {th }}$ day after transplanting, root length and plant height were measured and biomass of the whole rice plant was recorded after oven dry at $105^{\circ} \mathrm{C}$. Then, the treatments were compared with the control treatment to choose the best bacterial isolate which stimulate the growth and biomass of rice seedling for assays to evaluate effect of environmental factors on the IAA production of the best isolate. 


\subsection{Environmental and Physical Factors on IAA Production}

To check effect of environmental and physical factors on IAA production of the best bacterial strain (ST2-1) in term of concentrations of $\mathrm{NaCl}, \mathrm{pH}$, antibiotics and fungicides in NBRIP medium containing $1 \% \mathrm{NaCl}$. The ST2-1 strain was enriched in TSB liquid medium to obtain optical density $\left(\mathrm{OD}_{660 \mathrm{~nm}}=0.7\right)$ and the bacterial suspension was used for the following experiments.

\subsubsection{Effect of Different NaCl Concentration of Liquid} Medium on IAA Production of ST2-1 Bacterial Strain

The experiment was conducted to evaluate the effect of different concentrations of $\mathrm{NaCl}$ on IAA production ability of the ST2-1 strain, including four treatments $0 \%, 1 \%, 2 \%$ and $3 \% \mathrm{NaCl}$ in $100 \mathrm{~mL}$ Erlenmeyer flasks containing $29 \mathrm{~mL}$ NBRIP medium and then $1 \mathrm{~mL}$ bacterial suspension was added to obtain $3 \times 10^{4}$ CFUs. $\mathrm{mL}^{-1}$ as the initial bacterial density. Each treatment had a corresponding control that had the same concentrations of $\mathrm{NaCl}$ and culture medium as the actual treatment, but they did not have microbial inoculation. The experiment was carried out with three replicates for each treatment and the sample flasks were incubated on a shaker at $90 \mathrm{rpm}$ in the dark for 8 days (Bio-shaker BR-300LF, Taitec, Nagoya, Japan). Concentration of IAA production was measured at $0,1,3,6$ and 8 days after inoculation by Salkowski reagent at a $530 \mathrm{~nm}$ wavelength [31].

\subsubsection{Effect of Different pH Values of Liquid Medium on IAA Production of ST2-1 Bacterial Strain}

To determine effect of different $\mathrm{pH}$ values of NBRIP liquid medium containing $1 \% \mathrm{NaCl}$ on IAA production of the ST21 bacterial strain, an experiment was conducted. The manner of this experiment was similar to the experiment entitled "Effect of different $\mathrm{NaCl}$ concentration of liquid medium on IAA production of ST2-1 bacterial strain". Four treatments were established including four different $\mathrm{pH}$ values of liquid medium 3, 5, 7 and 9, together with four replicates for each treatment. The initial bacterial number of this ST2-1 strain was $3 \times 10^{4}$ CFUs.mL-1. Each treatment had a corresponding control that had the same $\mathrm{pH}$ value of liquid medium as the actual treatment, but they did not have microbial inoculation. The sample flasks were incubated on a shaker at $90 \mathrm{rpm}$ in the dark for 8 days (Bio-shaker BR-300LF, Taitec, Nagoya, Japan). Concentration of IAA production was measured at 0 , 1, 3, 6 and 8 days after inoculation by Salkowski reagent at a $530 \mathrm{~nm}$ wavelength [31].

\subsubsection{Evaluation of Antibiotic Sensitivity on IAA Production of ST2-1 Bacterial Strain}

A liquid experiment was conducted evaluate the antibiotic sensitivity on IAA production of ST2-1 bacterial strain. The liquid experiment was carried out with four treatments in NBRIP liquid medium comprising $1 \% \mathrm{NaCl}$, including three antibiotic treatments as follows Ampicillin, Chloramphenicol and Streptomycin at $100 \mathrm{mg} \cdot \mathrm{L}^{-1}$ concentration and the control treatment having the same amount of bacterial number, but antibiotic compounds were not applied. The initial bacterial number of ST2-1 strain was $3 \times 10^{4}$ CFUs.mL-1. The sample flasks were incubated on a shaker at $90 \mathrm{rpm}$ in the dark for 11 days (Bio-shaker BR-300LF, Taitec, Nagoya, Japan). Concentration of IAA production in NBRIP liquid medium was measured at $0,1,3,5,7$ and 11 days after inoculation by Salkowski reagent at a $530 \mathrm{~nm}$ wavelength [31].

\subsubsection{Evaluation of Fungicide Sensitivity on IAA Production of ST2-1 Bacterial Strain}

To evaluate fungicide sensitivity on IAA production of the ST2-1 bacterial strain, a liquid experiment was conducted in NBRIP medium, containing three different ingredients of fungicides as follows Thiophanate Methyl, Propineb and Mancozeb with recommended doses of 1000, 3125 and 3750 mg. $\mathrm{L}^{-1}$, respectively and the control treatment having the same amount of bacterial number, but fungicide compounds were not applied. The initial bacterial number of ST2-1 strain was $3 \times 10^{4}$ CFUs. $\mathrm{mL}^{-1}$. The sample flasks were incubated on a shaker at $90 \mathrm{rpm}$ in the dark for 11 days (Bio-shaker BR300LF, Taitec, Nagoya, Japan). Concentration of IAA production in NBRIP liquid medium was measured at $0,1,3$, 5,7 and 11 days after inoculation by Salkowski reagent at a $530 \mathrm{~nm}$ wavelength [31].

\subsection{Molecular Identification of IAA Producing Bacteria (ST2-1)}

The identification of IAA producing ST2-1 strain was done on the basis of $16 \mathrm{~S}$ rRNA gene sequencing. The genomic DNA of ST2-1 isolate was extracted using PowerSoil $^{\circledR}$ DNA Isolation Kit (MOBIO Laboratories, a QIAGEN Company, Valencia, CA). The primer 27F (5'-AGA GTT TGA TCC TGG CTC AG-3') and 1492R (5'-GGT TAC CTT GTT ACG ACT T-3') were used for amplification of $16 \mathrm{~S}$ rRNA gene (Lane, 1991). The total PCR reaction mixture was $50.0 \mu \mathrm{L}$ comprising $200.0 \mu \mathrm{M}$ dNTPs, $50.0 \mu \mathrm{M}$ each primer, $1 \mathrm{X}$ PCR buffer, 3U Taq polymerase, and $100.0 \mathrm{ng}$ genomic DNA. The thermocycling conditions involved an initial denaturation at $94^{\circ} \mathrm{C}$ for 5 minutes, followed by 35 cycles of $94^{\circ} \mathrm{C}$ for 1 minute, $55^{\circ} \mathrm{C}$ for 1 minute, and $72^{\circ} \mathrm{C}$ for 2 minutes and final extension at $72^{\circ} \mathrm{C}$ for 7 minutes. The sequences of the insert were determined using a Big-Dye Terminator Cycle Sequencer and an ABI Prism 310 Genetic Analyzer (Applied Biosystems, CA). The 16S rRNA gene sequences were analyzed using the gapped BLASTn (http://www.ncbi.nlm.nih.gov) search algorithm and aligned to their nearest neighbors.

\subsection{Statistical Analysis}

Data were analyzed ANOVA by Minitab 16 version compare average treatments.

\section{Results and Discussions}

\subsection{Isolation of IAA Producing Isolates}

The results of isolation shows that total 213 bacterial strains were successfully isolated on NBRIP medium 
comprising $1 \% \mathrm{NaCl}$ from 15 different soil samples located in the coastal area in the Mekong Delta of Vietnam. Forty five out of 213 strains showed their positive reaction in forming pink solution when reacted with Salkowski's reagent. Thus they were considered as potentially IAA producing isolates. The results of IAA production potential of these 45 isolates in NBRIP liquid medium containing $1 \%$ $\mathrm{NaCl}$ were shown as bellows.

\subsection{Characterization of IAA Production Potential}

The highest IAA concentration in NBRIP liquid medium containing $1 \% \mathrm{NaCl}$ produced by 45 bacterial isolates was presented in Figure 1. In this figure only the most ten IAA producing isolates were selected to present. It means that ten out of 45 isolates had an ability to produce high amount of IAA in NBRIP liquid medium modified with $1 \% \mathrm{NaCl}$. They were coded as BT1-1, CM6-1, CM6-2, CM6-3, KG4-1, ST21, ST6-1, CM6-4, KG3-1 and KG4-2. IAA concentration generated from ten bacterial strains varied between 10.44 and $33.13 \mathrm{mg} \cdot \mathrm{L}^{-1}$. Among these strains, the maximum IAA concentration in liquid medium was observed by ST2-1 (33.13 mg.L $\mathrm{L}^{-1}$ ) followed by CM6-1 (31.13 mg.L $\left.\mathrm{L}^{-1}\right)$ and BT1-1 (27.2 mg.L $\mathrm{L}^{-1}$ ) while ST6-1 was the worst one among ten selected isolates in term of IAA production ability (10.44 mg. $\left.\mathrm{L}^{-1}\right)$. Moreover, these ten isolates which produced IAA, were potentially also phosphate solubilizer since these strains were isolated from NBRIP medium which is specific medium for phosphate solubilizing microorganism isolation. The results of mean comparison related to different isolates indicate that concentrations of IAA produced by these isolates in this study are in agreement with the results of former studies, including [1,33-35]. In their reports bacterial isolates produced IAA in the range 5.34 to $25.4 \mathrm{mg} . \mathrm{L}^{-1}$. All these studies clearly reflect the ubiquitous nature of bacteria and their significance in promoting the growth of the associated biota. In this study ST2-1 can be considered as the best isolate in producing highest IAA concentration and this strain may help to promote the plant growth via many mechanisms and this strain was used for further investigations as a function of biofertilizer for plants.

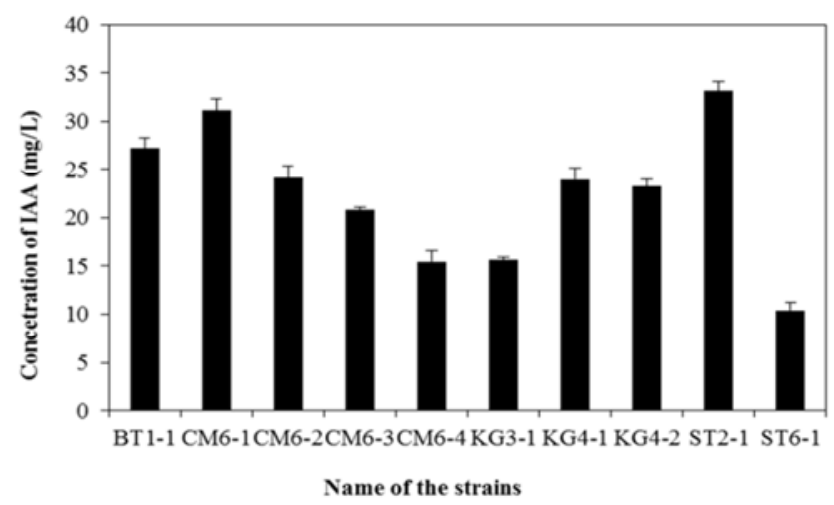

Figure 1. The highest IAA production in NBRIP liquid medium containing $1 \% \mathrm{NaCl}$ of ten selected bacterial isolates at day 8 (bars indicate \pm standard deviation).

\subsection{Effect of IAA Producing Bacterial Isolates on Plant Growth}

The results of plant height, root length and dried biomass of rice plant cultivated in Hoagland medium inoculated with ten different bacterial isolates at $7^{\text {th }}$ day after transplanting are presented in Figure 2. In this plant growth test, the maximum effect on the height of rice seedling was demonstrated by strain CM6-4 $(23.47 \mathrm{~cm})$ and followed by CM6-3 $(22.13 \mathrm{~cm})$. These two strains increased the plant height of inoculated rice seedlings over the control $(20.62$ $\mathrm{cm})$ whilst the root length of rice seedlings were elongated significantly over the control treatment by strain CM6-1; CM6-2; CM6-3; KG3-1; KG4-1; KG4-1; ST2-1 and ST6-1. The longest root of rice seedlings was observed by the strain ST2-1 $(6.23 \mathrm{~cm})$ while the root length of rice seedlings grown in Hoagland liquid medium inoculated by other strains varied between 3.24 and $6.07 \mathrm{~cm}$ (Figure 2A). Moreover, although the plant height of rice seedling inoculated with strain ST2-1 $(17.43 \mathrm{~cm})$ was significantly shorter than the other treatments even the control treatment $(20.62 \mathrm{~cm})$ $(\mathrm{P}<0.05)$, root length $(6.23 \mathrm{~cm})$ and total dried biomass $(16.30 \mathrm{mg})$ of rice seedlings inoculated with strain ST2-1 were significantly longer and higher than other treatments and even control treatment $(4.13 \mathrm{~cm}$ and $13.69 \mathrm{mg}$, respectively) (Figure 2B). This result indicates that the strain ST2-1 had the most favorable effect on the root length and dry biomass of rice seedlings whilst the strain CM6-4 had the optimal effect on shoot length of rice seedlings. Thus, it would say that IAA produced by this strain ST2-1 has a good function in increasing of root and biomass of rice seedlings. The IAA concentration production from this strain ST2-1 can promote the root length and dry biomass thus, it could help plant to take up more nutrients in soil and consequently it helps to improve biomass and yield of rice plant [36, 37]. In former studies showed that root elongation was found to occur in Sesbania aculeata by inoculation with Azotobacter spp. and Pseudomonas spp., in Brassica campestris by Bacillus spp [38] in Vigna radiata by Pseudomonas putida [1] and in Pennisetum americanum by Azospirillum brasilense [39]. Another study of Mohite (2013) [35] showed that the rhizosphere soil isolates were significantly augment the plant height and root length of wheat seedlings along with increase in chlorophyll content when compared with control. The property of synthesizing IAA is considered as effective tool for screening beneficial microorganisms suggesting that IAA producing bacteria have profound effect on plant growth [37]. Fatima et al., (2009) [36] also showed that germination rate, roots, shoot growth of plant were increased by IAA producing bacteria. Data obtained from this glass tube experiment demonstrated positive effect of this bacterial strain (ST2-1) on rice seedling growth and thus it can be considered as plant growth promoter. Hence, this strain is promising strain used as bio-fertilizer source in agricultural application. 


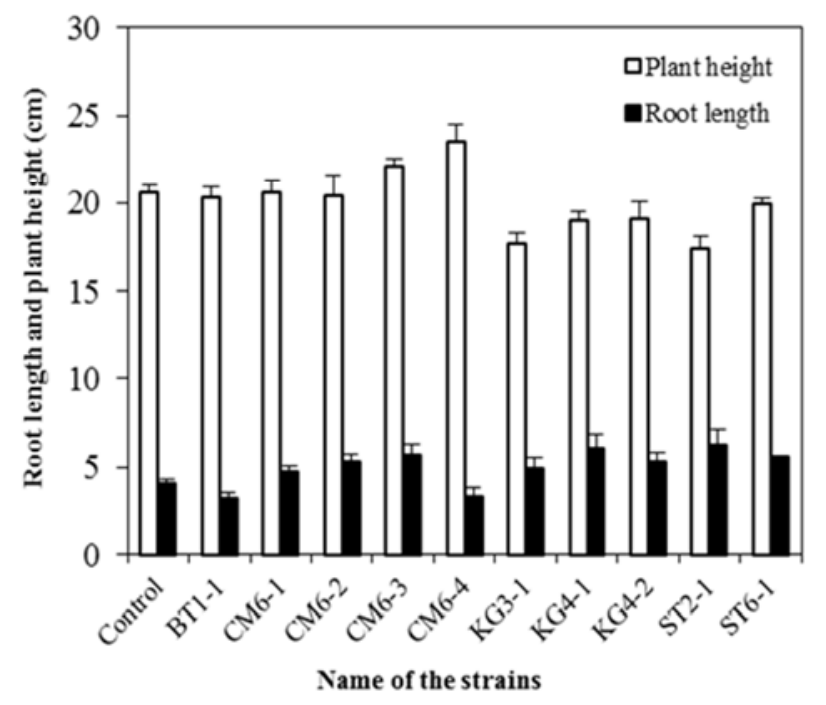

(A)

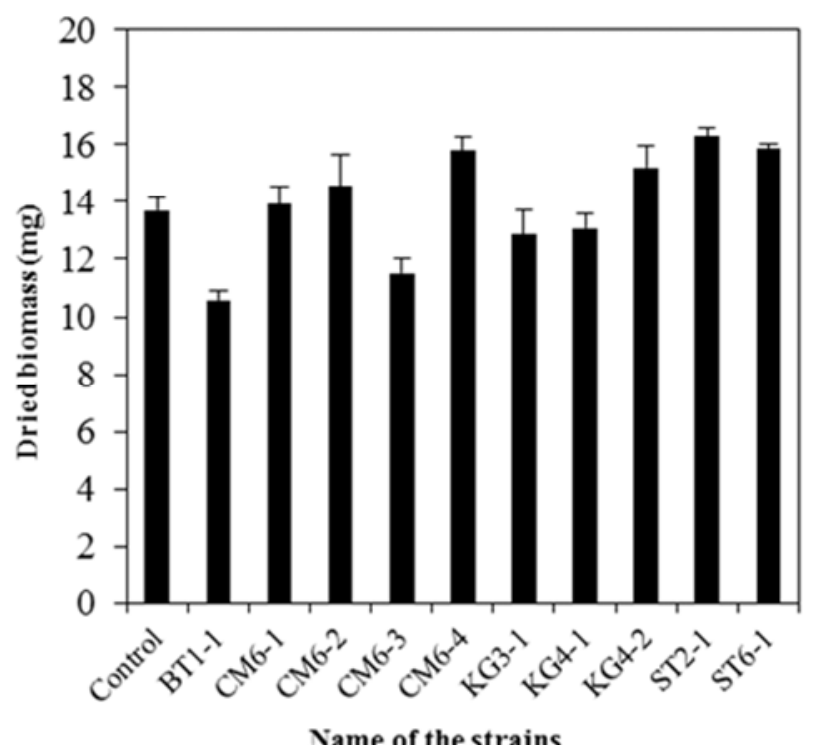

(B)

Figure 2. Root length, plant height and dried biomass of rice seedlings grown in Hoagland liquid medium inoculated with different bacterial strains at day 7 after transplanting (bars indicate \pm standard deviation).

\subsection{Environmental and Physical Factors on IAA Production}

\subsubsection{NaCl Concentration}

The salt tolerance of the selected bacterial strain, ST2-1 was determined by the products of IAA produced in NBRIP liquid medium supplemented with $0-3 \% \mathrm{NaCl}$. The results showed this strain was able to grow and produce IAA product in NBRIP liquid medium plus $0-3 \%(\mathrm{w} / \mathrm{v}) \mathrm{NaCl}$ (Table 2). The highest percentage of $\mathrm{NaCl}$ to $3 \%(\mathrm{w} / \mathrm{v})$ suppressed the IAA production of this strain in NBRIP liquid medium. Therefore, IAA production capacity of ST2-1 cultivated in NBRIP liquid medium plus 1, 2, and 3\% (w/v) $\mathrm{NaCl}$ was investigated to confirm its tolerance and this ST2-1 could be classified as halotolerant bacteria [40]. All the $\mathrm{NaCl}$ concentrations enhanced the IAA production of the bacterial strain ST2-1 as compared to the control treatment, $0 \% \mathrm{NaCl}$. The maximum IAA production produced by ST2-1 in the NBRIP liquid medium varied between 25.94 and $29.55 \mathrm{mg}$. $\mathrm{L}^{-}$ 1 , significantly higher than that of the control treatment (11.92 mg. $\mathrm{L}^{-1}$ ). However, at the concentrations of 1 and $2 \%$ $\mathrm{NaCl}$, IAA productions produced by ST2-1 were not significantly different with each other, but these two IAA productions were significantly higher than that of the treatment with $3 \% \mathrm{NaCl}$. Thus, this result showed that the maximum IAA (28.65-29.55 mg. $\left.\mathrm{L}^{-1}\right)$ productions were found at 1 and $2 \% \mathrm{NaCl}$ and this strain can tolerant the environmental stress to $3 \% \mathrm{NaCl}$. In the case of IAA production, IAA is an auxin required by most plant cells for division and root initiation [41]. Egamberdiyeva (2009) [42] reported that IAA-producing bacteria significantly increased plant growth under salt stress. In addition, Nakbanpote et al., (2014) [43] also reported that Pseudomonas sp. $\mathrm{PDMZnCd} 2003$ isolated from from a $\mathrm{Zn} / \mathrm{Cd}$ contaminated soil was classified as salt-tolerant bacteria. This bacteria had indole-3-acetic acids (IAA) production, nitrogen fixation, and phosphate solubilization, under $8 \%(\mathrm{w} / \mathrm{v}) \mathrm{NaCl}$ condition, moreover, this strain stimulated the germination and seedlings of Oryza sativa L.cv. RD6 under a salinity of 0-16 $\mathrm{dS} \cdot \mathrm{m}^{-1}$. Therefore, the isolate of ST2-1 which was halotolerant bacteria is considered as plant growth promoting bacteria.

\subsection{2. pH of Culture Medium}

The highest IAA production by the strain, ST2-1 in different $\mathrm{pH}$ level media is presented in Table 2. The low $\mathrm{pH}$ retards plant growth, because the concentrations of metals $\left(\mathrm{Al}^{3+}\right.$ and $\left.\mathrm{Mn}^{2+}\right)$ in the soil solution can make metals more bioavailable to reach toxic levels. It is known that soil $\mathrm{pH}$ and metal cations may affect many processes occurring in the rhizosphere. The affect of different levels of $\mathrm{pH}$ (5-9) was determined. The IAA production by this ST2-1 strain was significantly different among different $\mathrm{pH}$ treatments. The maximum amount of IAA was produced by the isolate, ST21 in NBRIP liquid medium supplemented with $1 \% \mathrm{NaCl}$ when $\mathrm{pH}$ of the culture medium was 7 (23.46 mg. $\left.\mathrm{L}^{-1}\right)$, followed by $\mathrm{pH} 5$ (20.44 mg. $\left.\mathrm{L}^{-1}\right)$, pH 9 (3.25 mg. $\left.\mathrm{L}^{-1}\right)$ and $\mathrm{pH}$ 3 (0.86 mg. $\left.\mathrm{L}^{-1}\right)$. The result of this present study is in agreement with other former studies. Acidic $\mathrm{pH}$ medium (below 5 and over 7) was found to be unfavorable for IAA production by the isolate, ST2-1 in NBRIP liquid medium. Mandal et al., (2007) [44] have reported that the Rhizobium strain, VMA 301 for elaborated high levels of IAA production in a pH 7.2 medium. Khamna et al., (2010) [45] have shown that $\mathrm{pH} 7.0$ was suitable for maximum IAA production by Streptomyces sp. However, other $\mathrm{pH}$ value ranges of the medium were proven to be a favorable condition to have high IAA production by other bacterial species for other bacteria through many other former studies. IAA production by Bacillus spp. $\mathrm{MQH}-19$ was highest at $\mathrm{pH}$ 6.0 and decreased by $62 \%$ at $\mathrm{pH} 5.0$. For Paenibacillus spp. SPT-03, IAA production was highest at $\mathrm{pH} 5.0$ and decreased by $42 \%$ at $\mathrm{pH} 7.0$ [46]. The property of IAA is 
considered as effective tool for screening beneficial microorganisms suggesting that IAA producing bacteria have profound effect on plant growth [37]. Soil or plants inoculated with IAA producing bacteria induces the proliferation of lateral roots and root hairs. Fatima et al., (2009) [36] also showed that germination rate, roots, shoot growth of plant were increased by IAA and PGPR. Therefore this isolate was studied for its effect on plant growth under controlled conditions.

\subsubsection{Antibiotic Sensitivity}

Antibiotic sensitivity pattern of the halotolerant bacterial isolate was determined against three different antibiotics (Ampicillin, Chloramphenicol and Streptomycin) in NRRIP liquid medium containing $1 \% \mathrm{NaCl}$. Results showed in Table 2 depict that halotolerant bacterial isolate was sensitive to all the three tested antibiotics. This is indicted by that fact that IAA production was found highest in the control treatment which had no antibiotic supplementation. The most sensitivity of the ST2-1 strain was found for Streptomycin antibiotic where IAA production was $0.45 \mathrm{mg} \cdot \mathrm{L}^{-1}$. Among three antibiotics tested, Ampicillin was found to be less susceptible for this strain, ST2-1. The maximum IAA production produced by this strain in NBRIP liquid medium supplemented with $1 \% \mathrm{NaCl}$ was seen for Ampicillin treatment $\left(4.52 \mathrm{mg} . \mathrm{L}^{-1}\right)$, higher than that in treatment containing antibiotic Chloramphenicol $\left(1.20 \mathrm{mg} . \mathrm{L}^{-1}\right)$. In short, the halotolerant bacterial isolate, ST2-1 was sensitive to all the three tested antibiotics Ampicillin, Chloramphenicol and Streptomycin.

\subsubsection{Fungicide Sensitivity}

The results of the fungicide sensitivity are presented in Table 2. Results showed that the bacterial ST2-1 isolate was susceptible with all three tested fungicides (Thiophanate Methyl, Propineb and Mancozed) at the recommended rate. In the presence of these three fungicides amended in NBRIP liquid medium, the strain ST2-1 showed the maximum tolerance against Thiophanate Methyl (1000 mg. $\left.\mathrm{L}^{-1}\right)$ and the least tolerance against Propineb and Mancozed (3125 and $3750 \mathrm{mg} . \mathrm{L}^{-1}$, respectively). The fungicide tolerance results were proven through data of IAA production. IAA production in the control treatment which had no fungicide amendment was achieved highest (10.18 mg. $\left.\mathrm{L}^{-1}\right)$, significantly different from three other treatments amended with three different fungicides $(p<0.05)$. Among three different fungicide treatments, IAA production produced by the isolate ST2-1 in fungicide Thiophanate Methyl treatment was $8.42 \mathrm{mg} . \mathrm{L}^{-1}$, significantly higher than that in the two other treatments (Propineb and Mancozep, 2.38 and 2.96 mg. $\mathrm{L}^{-1}$, respectively). The strain ST2-1 did not produce IAA in the fungicide amended treatments as much as in the control treatment because these fungicides may be inhibited or change IAA producing metabolic pathway. The tolerance or resistance against pesticides including fungicides is a complex process of microorganisms regulated at both physiological and genetic level [47]. The toxicology of pesticides to organisms varies owing to their functional groups and a great degree of variability occurs even among pesticides of similar functional groups [48]. Most of the pesticides in our study have different functions groups. In our study, degree of inhibition of phyto-beneficial traits of the strain ST2-1 under pesticide stress hence differs from one pesticide to another. Additionally, pesticides not only damage structural proteins essential for the growth of the organism but also responsible for geno-toxicity [49] and eventually causes to the decreased functioning and survival of organisms exposed to high concentration of pesticides [50]. Fungicide accumulates in soils over the recommended level resulting from either by consistently repeated application or their slow degradation rate. It affects plant growth by altering plant root's architecture, number of root sites for rhizobial infection, transformation of ammonia into nitrates, transformation of microbial compounds to plants and vice versa. Besides this, growth and activity of free living or endophytic bacteria in soil has also been affected. It is evident from data that pesticide residue persisted in the agricultural soil may hamper the plant growth promoting ability of bacteria.

Table 2. Effect of environmental factors on maximum IAA production of bacterial strain, ST2-1.

\begin{tabular}{lll}
\hline $\begin{array}{l}\text { Environmental } \\
\text { factors }\end{array}$ & Treatment & $\begin{array}{l}\text { The maximum concentration } \\
\text { of IAA }\left(\mathbf{m g . L ^ { - 1 }}\right)\end{array}$ \\
\hline $\mathrm{NaCl}$ & $0 \% \mathrm{NaCl}$ & $11.92^{\mathrm{c}}( \pm 0.66)$ \\
concentrations & $1 \% \mathrm{NaCl}$ & $29.55^{\mathrm{a}}( \pm 0.39)$ \\
$(\%)$ & $2 \% \mathrm{NaCl}$ & $28.65^{\mathrm{a}}( \pm 0.50)$ \\
& $3 \% \mathrm{NaCl}$ & $25.94^{\mathrm{b}}( \pm 0.18)$ \\
& $\mathrm{pH}-3$ & $0.86^{\mathrm{d}}( \pm 0.59)$ \\
$\mathrm{pH}$ & $\mathrm{pH}-5$ & $20.44^{\mathrm{b}}( \pm 0.18)$ \\
& $\mathrm{pH}-7$ & $23.46^{\mathrm{a}}( \pm 0.87)$ \\
& $\mathrm{pH}-9$ & $3.25^{\mathrm{c}}( \pm 0.84)$ \\
& Control & $10.18^{\mathrm{a}}( \pm 0.16)$ \\
Antibiotics & Ampicillin & $4.52^{\mathrm{b}}( \pm 0.20)$ \\
& Chloramphenicol & $1.20^{\mathrm{c}}( \pm 0.29)$ \\
& Steptomycin & $0.45^{\mathrm{d}}( \pm 0.21)$ \\
& Control & $10.18^{\mathrm{a}}( \pm 0.16)$ \\
& Thiophanate & $8.42^{\mathrm{b}}( \pm 0.56)$ \\
\hline \multirow{2}{*}{ Fungicides } & Methyl & $2.38^{\mathrm{c}}( \pm 0.39)$ \\
& Propineb & $2.96^{\mathrm{c}}( \pm 0.88)$ \\
\hline
\end{tabular}

Values are average $(\mathrm{n}=3) ; \pm$ standard deviation

Averages with the same superscript within the same column are not significantly different at $5 \%$ level

\subsection{S rRNA Gene Sequencing}

Furthermore, the BLAST results of the 16S rRNA gene sequences allowed to classify the isolated strain from salt affected soil into the family of Bacillaceae. The evaluated strain was aligned against sequences available from GenBank data; the isolated strain, ST2-1 matched to Bacillus megaterium with $99 \%$ of similarity percentage through GenBank data base. The identified genera in this study have been associated with plant rhizosphere and their phosphatesolubilizing activity has also been reported earlier [23, 51, 52]. 


\section{Conclusions}

From this study, it is clear that soils in rice-shrimp rotational farming system in salt affected areas of the Mekong Delta, Vietnam can provide a rich source of IAA producing bacteria and has the ability to produce a significant amount of IAA in a NBRIP liquid medium without tryptophan supplementation. Overall ten isolates were identified as IAA producing strains among which one efficient IAA producing bacteria were characterized and environmental parameters were tested for IAA production. Among the isolates, the isolate ST2-1 show best growth promoting activity. It is concluded that presence of such growth promoting rhizoflora accountable for the beneficial effects on crop growth and yield. The significance of the study could be stated as the potential of this IAA producing isolate and environmental factors effecting on IAA production will stimulate the growth and ultimately IAA production in the field and prevent environmental pollution by avoiding excessive applications of industrially produced fertilizers to cultivated fields.

\section{References}

[1] Pattern CL, Glick BR. Role of Pseudomanas putida indo lactic acid in development of the host plant root system. Applied Environmental Microbiology. No. 68, 2002, pp. 3795-3801.

[2] Carreno-Lopez R, Campos-Reales N, Elmerich C, Baca BE. Physiological evidence for differently regulated tryptophandependent pathways for indole-3-acetic acid synthesis in Azospirillum brasilense. Mol. Gen. Genet. Vol. 264, No. 4, 2000, pp. 521-530.

[3] Matsukawa E, Nakagawa $Y$, Iimura $Y$, Hayakawa $M$. Stimulatory effect of indole-3-acetic acid on aerial mycelium formation and antibiotic production in Streptomyces spp. Actinomycetologica. Vol. 21, 2007, pp. 32-39.

[4] Horemans S, Vlassak K. Production of indol-3-acetic acid by Azospirillum brasilense. In: W. Klingmuller (Ed.), Azospirillum III: genetics, physiology, Ecology SpringerVerlag, Berlin. 1985.

[5] Glick BR. The enhancement of plant growth by free living bacteria. Canadian Journal of Microbiology. Vol. 4, 1995, pp. $1109-1114$.

[6] Buggei NRG, Craigie JS. Evaluation of evidence for the presence of indole-3-acetic acid in marine algae. Planta. Vol. 97, 1971, pp. 173-178.

[7] Teale WD, Paponov IA, Palme K. Auxin in action: signaling, transport and the control of plant growth and development. Mol. Cell Biol. Vol. 7, 2006, pp. 847- 859.

[8] Caumette P, Matheron R, Raymond N, Relexans JC. Microbial mats in the hypersaline ponds of Mediterranean salterns (Salins-de-Giraud, France). FEMS Microbiol. Ecol. Vol. 13, 1994, pp. 273-286.

[9] Oren A, Seckbach J. Oxygenic phothosynthetic microorganisms in extreme environments. Nova Hedwigia. Vol. 123, 2001, pp. 13-31.
[10] Lynch JM. Origin, nature and biological activity of aliphatic substances and growth hormones found in soil. In Vaughan D, Malcom RD (Eds). Soil Organic Matter and Biological Activity. Martinus Nijhoff W Junk Publishers. Dordrecht, Boston, Lancaster, 1985, pp. 151-174.

[11] Arshad M, Frankenberger WT. Microbial production of plant growth regulators. In: Metting FB Jr (eds). Soil Microbial Ecology, Marcel Dekker Inc., New York. 1992, pp. 307-347.

[12] Shih-Yung H. IAA production by Streptomyces scabies and its role in plant microbe interaction. Msc thesis, Cornell University. 2010.

[13] Datta C, Basu P. Indole acetic acid production by a Rhizobium species from root nodules of a leguminous shrub Cajanus cojan. Microbiol. Res. Vol. 155, 2000, pp. 123 - 127.

[14] Zhao Y. Auxin biosynthesis and its role in plant development. Annu. Rev. Plant Biol. Vol. 61: 2010, pp. 49-64.

[15] Gaskins MH, Albrecht SL, Hubble DH. Rhizosphere bacteria and their use to increase productivity: A Review. Agri. Eco. Environ., Vol. 12, 1985, pp. 99-116.

[16] Asghar HN, Zahir ZA, Arshad M, Khalik A. Relationship between in vitro production of auxins by rhizobacteria and their growth-promoting activities in Brassica juncea L. Biol. Fertil. Soils. Vol. 35, 2002, pp. 231-237.

[17] Arkhipova TN, Veselov SU, Melentiev AI, Martynenko EV, Kudoyarova GR. Ability of bacterium Bacillus subtilis to produce cytokinins and to influence the growth and endogenous hormone content of lettuce plants. Plant and Soil,. Vol. 272, 2005, pp. 201-209.

[18] Joo G J, Kim YM, Kim JT, Rhee IK, Kim JH, Lee IJ. Gibberellins-producing rhizobacteria increase endogenous gibberellins content and promote growth of red peppers. J. Microbiol. Vol. 43, 2005, pp. 510-515.

[19] Freitas JR, Banerjee MR, Germida JJ. Phosphate solubilizing rhizobacteria enhance the growth and yield but not phosphorus uptake of canola (Brassica napus). Biol. Fertil. Soils. Vol. 24, 1997, pp. 358-364.

[20] Owen A, Zlor R. Effect of cyanogenic rhizobacteria on the growth of velvetleaf (Abutilon theophrasti) and Corn (Zea mays) in autoclaved soil and the influence of supplemented glycine. Soil Biochem. Vol. 33, 2001, pp. 801-809.

[21] Pidello A. The effect of Pseudomonas fluorescens strains varying in pyoverdine production on the soil redox status. Plant Soil. Vol. 253, 2003, pp. 373-379.

[22] Chaiharn M, Chunhaleuchanon S, Kozo A, Lumyong S. Screening of rhizobacteria for their plant growth promoting activities. J. KMITL Sci. Tech. Vol. 8, 2008, pp. 18-23.

[23] Swain MR, Naskar SK, Ray RC. Indole 3-acetic acid production and effect on sprouting of yam. (Dioscorea rotundata L) Minisetts by Bacillus subtilis isolated from culturable cowdung microflora. Polish Journal of Microbiology. Vol. 56, 2007, pp. 103-110.

[24] Koga J, Adachi T, Hidaka H. Molecular cloning of the gene for indolepyruvate. 1991.

[25] Kosuge T, Sanger M. Indole acetic acid, its synthesis and regulation: basis for tumorigen city in plant disease. Recent Adv. Phytochem. Vol. 20, 1987, pp. 147-161. 
[26] Oberhansli T, Defago G, Haas D. Indole-3-acetic acid (IAA) synthesis in the biocontrol strain CHAO of Pseudomonas fluoresces: role of tryptophan side chain oxidase. J. Gen. Microbial. Vol. 137, 1991, pp. 2273-2279.

[27] Costacurta, A., Vanderleyden, J, 1995. Synthesis of phytohormones by plant associated bacteria. Crit. Rev. Microbiol., 21: 1-18.

[28] Yadav, S., David, A., Baluska, F., Bhatla, S. C, 2013. Rapid auxin-induced nitric oxide accumulation and subsequent tyrosine nitration of proteins during adventitious root formation in sunflower hypocotyls. Plant Signaling \& Behavior, 8: e23196.

[29] Horneck D, Sullivan A, Owen DM, Hart JM. Soil test interpretation guide. Oregon State University, Extension Service, EC 1478. 2011.

[30] Nautiyal SC. An efficient microbiological medium for screening phosphorus solubilizing microbiology. FEMS Microbiology Letter. Vol. 170, 1999, pp. 2017-2021.

[31] Brick JM, Bostock RM, Silverstone SE. Rapid in situ assay for indole acetic acid production by bacteria immobilized on nitrocellulose membrane. Applied Environmental Microbiology. Vol. 57, 1991, pp. 535-538.

[32] Hoagland DR, Arnon DI. The water culture method for growing plants without soil. California Agr. Exp. Sta. Cir. Vol. $337,1938$.

[33] Ahmad F, Ahmad I, Khan MS. Indole acetic acid production by indigenous isolates of Azotobacter and Pseudomonas fluorescent in the presence and absence of tryptophan. Turk. J. Biol. Vol. 29, 2005, pp. 29-34.

[34] Sachdev D, Chaudhari H, Kasture V, Dhavale D, Chopade B. Isolation and characterization of indole acetic acid (IAA) producing Klebsiella pneumoniae strains from rhizosphere of wheat (Triticum aestivum) and their effect on plant growth. Indian Journal of Experimental Biology. Vol. 47, 2009, pp. 993-1000.

[35] Mohite B. Isolation and characterization of indole acetic acid (IAA) producing bacteria from rhizospheric soil its effect on plant growth. Journal of Soil Science and Plant Nutrition. Vol. 13, No. 3, 2013, pp. 638-649.

[36] Fatima Z, Saleemi M, Zia M, Sultan T, Aslam M, Riaz-urRehman, Chaudhary MF. Antifungal activity of plant growthpromoting rhizobacteria isolates against Rhizoctonia solani in wheat. Afr. J. Biotechnol. Vol. 8, 2009, pp. 219-225.

[37] Wahyudi A T, Astuti R P, Widyawati A, Meryandini A, Nawangsih AA. Characterization of Bacillus sp. strains isolated from rhizosphere of soybean plants for their use as potential plant growth for promoting Rhizobacteria. Journal of Microbiology and Antimicrobials. Vol. 3, 2011, pp. 34-40.

[38] Ghosh, S., J. N. Penterman, R. D. Little, Chavez and B. R. Glick, 2003. Three newly isolated plant growth-promoting bacilli facilitate the seeding of canola, Brassica campestris. Plant Physol. Biochem. 41: 277-281.

[39] Tien TM, Gaskinsa MH, Hubbell1 NDDH. Plant growth substances produced by Azospirillurn brasilense and their effect on the growth of pearl millet (Pennisetum americanum L.). Appl. Environ. Microbiol. Vol. 37, 1979, pp. 1016-1024.

[40] Willey JM, Sherwood LM, Woolverton CJ. Prescott's principles of microbiology. New York: McGraw-Hill. 2009.

[41] Smith H. Phytochromes and light signal perception by plants an emerging synthesis. Nature. Vol. 407, 2000, pp. 585-591.

[42] Egamberdiyeva D. Alleviation of salt stress by plant growth regulators and IAA producing bacteria in wheat. Acta. Physiol. Plant. Vol. 31, 2009, pp. 861-864.

[43] Nakbanpote AW, Panitlurtumpaia N, Sangdeea A, Sakulponea N, Sirisoma P, Pimthong A. Salt-tolerant and plant growth promoting bacteria isolated from $\mathrm{Zn} / \mathrm{Cd}$ contaminated soil: identification and effect on rice under saline conditions. J. Plant Interact. Vol. 32, 2013, pp. 37-41.

[44] Mandal SK, Mondal KC, Dey S, Pati BR. Optimization of cultural and nutritional conditions for indole-3-acetic (IAA) production by a Rhizobium sp. Isolated from root nodules of Vigna mungo (L.). Helpper. Research journal of microbiology. Vol. 2, 2007, pp. 239-246.

[45] Khamna S, Yokota A, Peberdy JF, Lumyong S. Indole-3acetic acid production by Streptomyces sp. isolated from some Thai medicinal plant rhizosphere soils. Eur. Asia J. BioSci. Vol. 4, 2010, pp. 23-32.

[46] Acuna JJ, Jorquera1 MA, Martinez OA, Menezes-Blackburn D, Fernandez MT, Marschner P, Greiner R, Mora1 ML. Indole acetic acid and phytase activity produced by rhizosphere Bacilli as affected by $\mathrm{pH}$ and metals. Journal of Soil Science and Plant Nutrition. Vol. 11, 2011, pp. 1-12.

[47] Herman PL, Behrens M, Chakraborty S, Crastil BM, Barycki J, Weeks DP. A three component dicamba O-demethylase from Pseudomonas maltiphilia strain DI-6: gene isolation, characterization and heterologous expression. J. Biol. Chem. Vol. 280, 2005, pp. 24759-24767.

[48] Ahmed M, Khan MS. Functional aspects of plant growth promoting rhizobacteria: Recent advancements. Insight Microbiology. Vol. 1, 2011, pp. 39-54.

[49] Pham GH, Singh A, Malla R. Interaction of Piriformospora indica with diverse microorganisms and plants. Plant Surface Microbiol. (VarmaA, AbbottL, WernerD \& HamppR, eds). Springer-Verlag, Berlin. 2004, pp. 235-265.

[50] Kumar A, Maurya BR, Raghuwanshi R. Isolation and characterization of PGPR and their effect on growth, yield and nutrient content in wheat (Triticum aestivum L.). Biocatal. Agric. Biotechnol. Vol. 3, 2014, pp. 121-128.

[51] Starovic M, Josic D, Pavlovic S, Drazic S, Postic D, Popovic T, Stojanovic S. The effect of IAA producing Bacillus sp. Q3 strain on marshmallow seed germination. Bulgarian Journal Agriculture Science. Vol. 19, No. 3, 2013, pp. 572-577.

[52] Xu S, Zhou W, Pottinger S, Baldwin IT. Herbivore associated elicitor-induced defences are highly specific among closely related Nicotiana species. BMC Plant Biol. Vol. 15, 2015, pp. $2-10$. 